\title{
RESPIRATORY ENZYMES
}

\section{Respiratory Enzymes}

By University of Wisconsin Biochemists, under the direction of C. A. Elvehjem and P. W. Wilson. Pp. $\nabla+236$. (Minneapolis: Burgess Publishing Co., 1939.) 3.25 dollars.

$\mathrm{T}$

HE rapid developments during recent years in our knowledge of respiratory enzyme systems have created a demand for a book which, whilst giving an accurate and coherent account of these developments, indicates the nature of the experimental work leading up to them and shows the manner in which they are interrelated. Much of the relevant information which has been sum. marized so far, is to be found in authoritative but somewhat scattered review articles. It would obviously be a convenience to the student and to the experimental worker to have at hand a reasonably accurate account of the present state of the subject, in which sufficient of the older work is discussed to provide a proper perspective for the appreciation of the value of recent contributions.

The volume under review presents such a summary. It consists of a series of articles, reproduced from typescript, bearing on various aspects of respiratory enzyme systems, each article being written by a member, or by a number of members, of a group of workers engaged in enzyme research at the University of Wisconsin. A historical introduction to the subject by Prof. Elvehjem is followed by chapters on dehydrogenases and oxidases. Then come articles on cnenzymes, cytochrome, flavoproteins, etc., an article on the specific and non-specific poisons of respiratory processes and one on hydrogen transport systems. Finally, there are useful chapters on oxidation. reduction potentials, and on the physical-chemical theory of enzyme reactions.

The chapters vary considerably in style and in the thoroughness with which their subject-matter has been treated. Some overlapping has been inevitable. The volume has obviously been com. piled with great care, and the reviewer has noticed no misrepresentations of fact or of interpretation. The book should be very helpful to the student and to the worker about to commence research on respiratory enzyme systems.

J. H. Q.

\section{THE FAUNA OF THE SEASIDE}

The Littoral Fauna of Great Britain

A Handbook for Collectors. By Dr. N. B. Eales. Pp. xvii $+302+25$ plates. (Cambridge: At the University Press, 1939.) 12s. $6 d$. net.

\section{A} COUPIE of generations ago, the science of zoology ran a serious risk of being embedded in paraffin. This calamity was happily averted, and the young naturalist hies again to the seashore; but the first line of Dr. N. B. Eales's preface suggests that the poisonous breath of the examiner follows him even there. It may be so ; but the fresh air, and the spirit of Edward Forbes and Sir John Graham Dalyell cleanse and sanctify the place, and keep it as sweet as ever. In Edward Forbes's day and for years afterwards, we led the way in the literature of natural history. Forbes and Hanley, Yarrell's "Birds" and Gould's, the early British Museum catalogues, the Ray Society volumes and the Challenger Reports had no rivals. Alas, it is not so now. We might have undertaken the new "Systema Nature", but Berlin took the
"Tierreich" in hand. There is a "Fauna of the North Sea", but it is written in German ; there is an excellent "Faune de France", but none of the British seas.

Dr. Eales has not attempted the task, too big for one pair of hands, of writing a British Fauna, but she has compiled a careful and copious account of the fauna of the sandy beach and the rockpools; and the shore-fauna is liberally interpreted, for while the sea-mouse must stay outside, the feather-star and the purple heart-urchin, and pinna and the oyster itself are allowed to enter in. Philip Henry Gosse did the same thing more than eighty years ago, and the two little green volumes of his "Manual of the Marine Zoology for the British Isles" were used and loved by many. His plan was different from Dr. Eales's; for he included all the species as best he could but only defined the genera, while Dr. Eales defines the species, but only a selection of these. Gosse's illustrations were the best part of his book; they were only thumb-nail sketches, but they were 